\title{
Carcass characteristics of lambs fed diets containing silage of different genotypes of sorghum
}

\author{
Juraci Marcos Alves Suassuna', Edson Mauro Santos², Juliana Silva de Oliveira², Paulo Sérgio \\ de Azevedo², Wandrick Hauss de Sousa ${ }^{3}$, Ricardo Martins Araujo Pinho², João Paulo de Farias \\ Ramos $^{3}$, Higor Fábio Carvalho Bezerra ${ }^{2}$
}

\footnotetext{
${ }^{1}$ Departamento de Zootecnia, Universidade Federal Rural de Pernambuco, Recife, PE, Brasil.

2 Departamento de Zootecnia, Universidade Federal da Paraíba, Areia, PB, Brasil.

${ }^{3}$ Empresa Estadual de Pesquisa Agropecuária da Paraíba, Soledade, PB, Brasil.
}

ABSTRACT - Thirty-five feedlot lambs (without defined breed, aged between 5 and 7 months, with average live weight of $17.7 \pm 3.7 \mathrm{~kg}$ ) were used in a completely randomized design to evaluate the effect of diets containing different genotypes of sorghum on morphometric measurements and qualitative characteristics of carcass and yields of primal cuts. The animals stayed in individual indoor pens for 42 days and slaughtered at an average weight of $26.24 \mathrm{~kg}$. No significant differences were observed on morphometric measurements, hot $(11.67 \mathrm{~kg})$ and cold $(11.39 \mathrm{~kg})$ carcass weight, hot $(44.46 \%)$ and cold $(43.37 \%)$ carcass yields, biological yield and on cooling losses. There was also no significant effect of silages of different genotypes of sorghum on the weights and yields of retail cuts (neck, shoulder, rib, loin and leg) and on the subjective evaluation of carcasses. It is possible to finish sheep without defined breed feeding them diets based on silages of sorghum, resulting in carcasses with high yield and good conformation.

Key Words: feedlot, primal cuts, production systems, sheep

\section{Introduction}

The Brazilian Northeast has the largest sheep flock in the country, and sheep are a species that represents an important activity in the development of that region. However, the problems with the seasonality of forage production are factors that contribute to a smaller development of this activity, which may compromise the animal-performance indexes achieved.

The use of high supplementation during both the rainy and dry seasons has been one of the mechanisms used by producers to solve the problem of forage shortage throughout the year; hence the importance of choosing fodder species and management systems that solve the problems faced by farmers in these regions.

Because sorghum presents anatomical and physiological characteristics that make it a species highly resistant to sites that show irregularities in the distribution of rainfall, it has been one of the most used species by producers in the Brazilian Northeast.

Despite its yield potential and adaptability to the Brazilian semiarid climate, there is availability of seed from cultivars of different purposes in the market, some fodder and others with a higher proportion of grain, making it necessary to evaluate whether the morphological characteristics of the plant influence the quality of the diet, and thus, the carcass characteristics of feedlot sheep.

In spite of being more productive, the forage sorghum presents few grains, which could result in less energy in the formulated diets. On the other hand, is spite of its higher nutritional value, grain sorghum is less productive than forage sorghum, resulting in more expensive silages. Thus, it is very important to evaluate not only agronomic characteristics but also animal response, as well carcass characteristics of animals to indicate the most appropriate form of sorghum for a given production system.

According to Ribeiro et al. (2002), finishing lambs in feedlot is viable when low-cost forage is available during the dry season. In the Brazilian Northeast, this practice is more recommended for semi-arid areas during the dry season, where there is a great lack of forage on pastures, allowing the producers in these regions to supply animals for slaughter throughout the year. Therefore, knowledge of diets that influence carcass characteristics of feedlot sheep is important so that they can deliver good-quality products that meet the demands of various consumer markets.

This study was conducted to evaluate the morphometric measurements and qualitative characteristics of carcass and yields of primal cuts of feedlot lambs without defined breed fed diets containing different genotypes of sorghum. 


\section{Material and Methods}

Thirty-five non-castrated lambs without defined breed (WDB) aged between 5 and 7 months, with average weight of $17.7 \pm 3.7 \mathrm{~kg}$, were used. The animals were initially vaccinated against clostridial diseases and treated against ecto- and endoparasites and, then, were distributed into indoor individual pens $(0.80 \times 1.20 \mathrm{~m})$, with free access to feed and water. The adaptation period lasted 11 days and the animals were weighed every 14 days to control their weight development.

The experiment was conducted in a completely randomized design, with five total-mixed-ration (TMR) treatments (Table 1). Five genotypes of sorghum were evaluated, in the form of silage: BRS 610, 655, 800 and 810, and Ponta Negra - the first four being developed by the breeding program of EMBRAPA Milho e Sorgo and the last of them by EMPARN - Empresa de Pesquisa Agropecuária do Rio Grande do Norte. The genotypes have the following characterizations: hybrids BRS 610, BRS
655, Ponta Negra are forage type, and hybrids BRS 800 and BRS 810 are of dual purpose (grain and/or forage). All genotypes were chosen because they present yield potential and adaptability to the region of study as demonstrated in previous research.

The total mixed rations were formulated based on the NRC (2007), predicting gains of $200 \mathrm{~g} /$ day, with forage proportion ranging from 45.11 to $50.98 \%$; values adjusted as a function of crude protein content. After previous analysis of the crude protein content of feedstuffs (Table 1), their proportion in the experimental diets was elaborated as described in Table 2. The intake of feed and water was ad libitum. Animals were fed twice a day (at 07.30 and $14.30 \mathrm{~h}$ ) and feed offered and refused were recorded daily to adjust feed offered for 0.10 refusal.

Composite samples of dietary ingredients offered and refused were analyzed for contents of dry matter, organic matter, ash, crude protein $(\mathrm{CP})$ and ether extract, according to methodologies cited by Silva and Queiroz (2002), and neutral detergent fiber corrected for ash and protein

Table 1 - Chemical composition of the ingredients utilized in the experimental diets

\begin{tabular}{|c|c|c|c|c|c|c|c|}
\hline \multirow[b]{2}{*}{ Items } & \multicolumn{7}{|c|}{ Feedstuffs } \\
\hline & $\begin{array}{l}\text { BRS } 610 \\
\text { silage }\end{array}$ & $\begin{array}{l}\text { BRS } 655 \\
\text { silage }\end{array}$ & $\begin{array}{l}\text { BRS } 800 \\
\text { silage }\end{array}$ & $\begin{array}{l}\text { BRS } 810 \\
\text { silage }\end{array}$ & $\begin{array}{c}\text { Ponta Negra } \\
\text { silage }\end{array}$ & $\begin{array}{c}\text { Ground corn } \\
\text { grain }\end{array}$ & $\begin{array}{c}\text { Soybean } \\
\text { meal }\end{array}$ \\
\hline Dry matter (DM), g/kg & 224.6 & 271.2 & 269.5 & 266.7 & 251.2 & 867.3 & 880.8 \\
\hline Organic matter, g/kg DM & 932.2 & 944.9 & 944.9 & 941.6 & 952.4 & 945.0 & 945.0 \\
\hline Ash, g/kg DM & 67.8 & 55.1 & 55.1 & 58.4 & 47.6 & 55.1 & 55.0 \\
\hline Crude protein, g/kg DM & 35.8 & 54.7 & 53.3 & 55.3 & 44.0 & 89.8 & 454.4 \\
\hline Ether extract, g/kg DM & 56.0 & 59.1 & 44.4 & 61.1 & 68.8 & 41.5 & 35.1 \\
\hline NDF corrected for ash and protein, $\mathrm{g} / \mathrm{kg} \mathrm{DM}$ & 519.7 & 467.2 & 477.1 & 481.2 & 545.0 & 118.4 & 138.6 \\
\hline Non-fibrous carbohydrates, $\mathrm{g} / \mathrm{kg}$ DM & 320.7 & 364.0 & 370.1 & 344.0 & 294.7 & 695.3 & 316.9 \\
\hline Total carbohydrates, g/kg DM & 840.4 & 831.1 & 847.2 & 825.3 & 839.7 & 813.7 & 455.5 \\
\hline
\end{tabular}

NDF - neutral detergent fiber.

Table 2 - Proportion of ingredients and average chemical composition of experimental diets

\begin{tabular}{|c|c|c|c|c|c|}
\hline \multirow{2}{*}{ Items } & \multicolumn{5}{|c|}{ Experimental diets ${ }^{1}$} \\
\hline & 610 & 655 & 800 & 810 & $\mathrm{PN}$ \\
\hline Sorghum silage, $\mathrm{g} / \mathrm{kg} \mathrm{DM}$ & 451.1 & 496.2 & 509.8 & 508.5 & 501.5 \\
\hline Ground corn grain, g/kg DM & 390.7 & 378.3 & 362.5 & 36.18 & 346.6 \\
\hline Soybean meal, g/kg DM & 111.7 & 80.5 & 83.8 & 85.9 & 108.0 \\
\hline Urea, g/kg DM & 6.9 & 6.3 & 6.2 & 6.2 & 6.4 \\
\hline Ammonium chloride, $\mathrm{g} / \mathrm{kg}$ DM & 10.1 & 9.3 & 9.0 & 9.0 & 8.1 \\
\hline Trace mineral salts ${ }^{2}, \mathrm{~g} / \mathrm{kg} \mathrm{DM}$ & 22.6 & 21.4 & 20.6 & 20.7 & 20.2 \\
\hline Limestone, g/kg DM & 8.9 & 8.1 & 8.1 & 7.9 & 9.2 \\
\hline Dry matter (DM), $\mathrm{g} / \mathrm{kg}$ & 381.6 & 417.0 & 409.1 & 406.4 & 390.9 \\
\hline Organic matter, g/kg DM & 895.2 & 902.5 & 903.5 & 901.9 & 907.2 \\
\hline Ash, g/kg DM & 104.8 & 97.5 & 96.5 & 98.1 & 92.8 \\
\hline Crude protein, g/kg DM & 165.4 & 166.1 & 164.0 & 167.1 & 162.9 \\
\hline NDF corrected for ash and protein, $\mathrm{g} / \mathrm{kg} \mathrm{DM}$ & 296.1 & 287.7 & 297.7 & 299.4 & 329.3 \\
\hline Non-fibrous carbohydrates, g/kg DM & 451.7 & 469.1 & 467.3 & 453.7 & 423.0 \\
\hline Total carbohydrates, g/kg DM & 747.8 & 756.9 & 765.1 & 753.2 & 752.3 \\
\hline Ether extract, g/kg DM & 45.4 & 47.9 & 40.6 & 49.1 & 52.7 \\
\hline
\end{tabular}

$\mathrm{NDF}$ - neutral detergent fiber.

${ }^{1} 610$ - Silage of sorghum BRS610; 655 - silage of sorghum BRS655; 800 - silage of sorghum BRS800; 810 - silage of sorghum BRS810; PN - silage of sorghum Ponta Negra.

${ }^{2}$ Each 1,000 g contains: vitamin A - 135,000.00 IU; vitamin D3 - 68,000.00 IU; vitamin E - $450.00 \mathrm{IU} ; \mathrm{Ca}-240 \mathrm{~g} ; \mathrm{P}-71 \mathrm{~g}$ (solubility in citric acid at 2\% [min.]); K - $28.2 \mathrm{~g}$; S - 20 g;

$\mathrm{Mg}$ - 20 g; Cu - 400 mg; Co - 30 mg; Cr - 10 mg; Fe - 2,500 mg; I - 40 mg; Mn - 1,350 mg; Se - 15 mg; Zn - 1,700 mg; maximum Fl - 710 mg; excipient q.s. - 1,000 g. 
(NDFap) by the method of Van Soest et al. (1991) with modifications proposed by the manual of Ankon (Ankon ${ }^{\circledR}$ Technology Corp.), corrected for the content of ash and crude protein.

After 42 days in the feedlot, the animals were deprived of solids and received only water for 16 hours. After this time, they were weighed to obtain the slaughter weight (SW). The slaughter was carried out in accordance with the standards of Regulamento de Inspeção Industrial e Sanitária dos Produtos de Origem Animal (Brasil, 2007). The animals were desensitized by stunning with brain concussion through a captive bolt pistol, followed by sticking, bleeding, dressing and evisceration. The blood was collected in previously tared container for later weighing.

After dressing and evisceration, the head (section in atlanto-occipital joint) and legs (section in carpal and tarsal-metatarsal joints) were removed, later recording the hot carcass weight $(\mathrm{HCW})$, and the $\mathrm{pH}$ and the internal temperature of the carcass ( 0 hours post mortem), in the semimembranosus muscle were measured. The gastrointestinal tract (GIT), bladder (B) and gallbladder (GB) were emptied and washed to obtain the empty body weight (EBW), which was estimated by subtracting the weights referring to the content of the GTI, B and GB from the weight at slaughter (WS), in order to determine the biological or true yield $[\mathrm{BY}=(\mathrm{HCW} / \mathrm{EBW}) \times 100]$.

Then the carcasses were cooled in cold chamber for 24 hours at $\pm 4{ }^{\circ} \mathrm{C}$, hanging by common calcaneal tendon. During the cooling period, at the semimembranosus muscle, the $\mathrm{pH}$ and carcass temperature were recorded 24 hours post mortem. After this period, the carcasses were weighed to obtain the cold carcass weight (CCW) and weight loss by cooling $[\mathrm{LC}=(\mathrm{HCW}-\mathrm{CCW}) / \mathrm{HCW} \times 100]$.

Subsequently, morphometric measures were taken of thoracic and hind widths; thoracic depth; thoracic, hind and leg perimeters; internal and external carcass lengths and leg length of carcasses, as shown by Garcia et al. (2003). After obtaining morphometric measures, the compactness index of carcass was determined by the ratio between weight and internal length of carcass.

The carcasses were subjectively evaluated, in which the conformation index $[1=$ Poor (concave), $2=$ Regular (subconcave), 3 = Good (straight), 4 = Very good (sub-convex), $5=$ Excellent (convex) $]$ and the degree of fattening $(1=$ Very thin, $2=$ Thin, $3=$ Median, $4=$ Fat, $5=$ Very fat) were determined, as proposed by Cezar and Sousa (2007). When assessing the renal-pelvic fat (RPF), a score varying from 1 to 3 was given, as follows: $1=$ Low (two uncovered kidneys), 2 = Normal (one covered kidney), $3=$ Excess (two covered kidneys) (Cezar and Sousa, 2007).
After subjective assessment of RPF of the carcass, the kidneys and pelvic + kidney fat were removed; their weights were recorded and subtracted from the hot and cold carcass weights. Then the hot $[\mathrm{HCY}=(\mathrm{HCW} / \mathrm{LWS}) \times 100]$ and the cold carcass yields $[\mathrm{CCY}=(\mathrm{CCW} / \mathrm{LWS}) \times 100]$ were calculated.

The carcasses were split longitudinally, at midline, and the left half-carcasses were weighed and sectioned into five regions (leg, loin, ribs, shoulder and neck) as presented by Colomer-Rocher et al. (1986).

The left half-carcass were cross-sectioned between the 12th and 13th thoracic vertebra, where the thickness of subcutaneous fat on the longissimus muscle was determined with a digital caliper. The marbling degree of the longissimus muscle was determined in a 1-5 scale according Osorio and Osorio (2005).

The data were subjected to analysis of variance (ANOVA), and when necessary, the means were compared by Tukey's test at $5 \%$ probability using the SISVAR statistical analysis program (Ferreira, 2008).

\section{Results and Discussion}

The silages of different genotypes of sorghum did not affect $(\mathrm{P}>0.05)$ the morphometric characteristics of the carcass (Table 3 ). This result is mainly due to the fact that the animals belonged to the same genetic group and were slaughtered at similar live weight, because all diets met the nutritional requirements of the animals. Thus, because these variables are influenced by genotypes of animals (Ribeiro et al., 2012), the probability of variations occurring due to diet modification is very low.

The silages of different genotypes of sorghum had no influence $(\mathrm{P}>0.05)$ on slaughter weight, empty body weight, and hot and cold carcass weights (Table 4), which may be related to the fact that different types of sorghum did not influence the nutritional value of diets, resulting in similar carcass and final weight between treatments.

With regard to the carcass yields, there was no difference $(\mathrm{P}>0.05)$ between treatments, and the animals showed average values of 58.47, 44.46 and $43.37 \%$ for biological, hot and cold carcass yields, respectively. Alves et al. (2012) found hot and cold carcass yields of 47.29 and $45.49 \%$, respectively, in feedlot lambs fed diets containing sorghum silages with high tannin. According to Cezar (2004), the biological yield best represents the components of the carcass because it eliminates variations influenced by the abiotic content. The hot carcass yield is the most used by producers, while the cold carcass yield is the most feasible by cold storages and the most important for the sheep-meat production chain. 
The average cooling loss found in this study was $2.45 \%$, which is lower than the $4.18,3.33$ and $2.88 \%$ found by Dantas et al. (2008) in Santa Inês lambs on pasture, fed concentrate at $0.0,1.0$ and $1.5 \%$ of their live weigh, respectively. Cooling losses are inversely related to the fattening degree of the carcasses, since the fat thickness provides protection to carcasses during the cooling period, reducing losses. In this work, the cooling loss of the carcasses can be considered low, since, according to Sañudo et al. (1981), for beef lambs, acceptable values range from 3 to $4 \%$, showing that, despite their undefined breed, the animals showed a good carcass fattening (Table 5), sufficient to provide protection to carcasses during cooling.
There was no difference $(\mathrm{P}>0.05)$ between the carcass compactness (CC) of the animals, which had an average value of $0.20 \mathrm{~kg} / \mathrm{cm}$. This measurement is used to evaluate the production of muscles between animals of similar body weight. The data regarding the carcass compactness found in this experiment show good proportion of muscle per length unit, and a good homogeneity of the animals used in the experiment. Therefore, the CC and slaughter weight data showed the homogeneity of the animals used in the experiment.

The silage of different genotypes of sorghum did not influence $(\mathrm{P}>0.05)$ the initial and final temperature of the meat, and also did not affect the $\mathrm{pH}$ of the meat, which had

Table 3 - Carcass morphometric measurements of lambs WDB fed diets containing different genotypes of sorghum

\begin{tabular}{|c|c|c|c|c|c|c|}
\hline \multirow{2}{*}{ Variables $(\mathrm{cm})$} & \multicolumn{5}{|c|}{ Genotypes of sorghum ${ }^{1}$} & \multirow{2}{*}{$\mathrm{P}$-value } \\
\hline & 610 & 655 & 800 & 810 & $\mathrm{PN}$ & \\
\hline External carcass length & 53.85 & 55.42 & 54.14 & 54.42 & 53.0 & 0.103 \\
\hline Internal carcass length & 55.57 & 56.42 & 56.0 & 56.92 & 55.14 & 0.444 \\
\hline Thoracic width & 17.71 & 17.92 & 17.64 & 16.92 & 18.28 & 0.717 \\
\hline Hind width & 17.71 & 17.57 & 16.64 & 17.14 & 17.85 & 0.789 \\
\hline Thoracic depth & 23.50 & 23.42 & 23.21 & 24.07 & 23.28 & 0.677 \\
\hline Hind perimeter & 54.85 & 54.64 & 54.14 & 54.78 & 55.14 & 0.980 \\
\hline Thoracic perimeter & 62.28 & 63.57 & 63.50 & 64.14 & 63.42 & 0.817 \\
\hline Leg perimeter & 35.35 & 35.0 & 35.14 & 34.85 & 35.14 & 0.988 \\
\hline Leg length & 38.35 & 38.21 & 38.64 & 38.92 & 39.28 & 0.706 \\
\hline
\end{tabular}

${ }^{1} 610$ - silage of sorghum BRS 610; 655 - silage of sorghum BRS 655; 800 - silage of sorghum BRS 800; 810 - silage of sorghum BRS 810; PN - silage of sorghum Ponta Negra.

Table 4 - Carcass characteristics of lambs WDB fed diets with different genotypes of sorghum

\begin{tabular}{|c|c|c|c|c|c|c|}
\hline \multirow{2}{*}{ Variables } & \multicolumn{5}{|c|}{ Genotypes of sorghum $^{1}$} & \multirow{2}{*}{ P-value } \\
\hline & 610 & 655 & 800 & 810 & $\mathrm{PN}$ & \\
\hline Slaughter weight (kg) & 25.68 & 26.77 & 26.28 & 26.54 & 25.91 & 0.925 \\
\hline Empty body weight (kg) & 20.43 & 20.86 & 20.57 & 20.29 & 20.71 & 0.911 \\
\hline Biological yield (\%) & 58.3 & 57.59 & 57.44 & 61.02 & 58.02 & 0.345 \\
\hline Hot carcass weight (kg) & 11.46 & 11.61 & 11.55 & 12.06 & 11.70 & 0.933 \\
\hline Hot carcass yield (\%) & 44.50 & 43.37 & 43.91 & 45.40 & 45.14 & 0.276 \\
\hline Cold carcass weight (kg) & 11.13 & 11.38 & 11.29 & 11.74 & 11.43 & 0.946 \\
\hline Carcass compactness $(\mathrm{kg} / \mathrm{cm})$ & 0.20 & 0.20 & 0.20 & 0.21 & 0.21 & 0.870 \\
\hline \multicolumn{7}{|l|}{ Temperature $\left({ }^{\circ} \mathrm{C}\right)$} \\
\hline 0 hours & 33.91 & 32.75 & 32.74 & 34.12 & 33.41 & 0.385 \\
\hline 24 hours & 4.14 & 4.14 & 3.98 & 4.05 & 4.01 & 0.580 \\
\hline \multicolumn{7}{|l|}{$\mathrm{pH}$} \\
\hline
\end{tabular}

${ }^{1} 610$ - silage of sorghum BRS 610; 655 - silage of sorghum BRS 655; 800 - silage of sorghum BRS 800; 810 - silage of sorghum BRS 810; PN - silage of sorghum Ponta Negra.

Table 5 - Subjective and subcutaneous fat thickness evaluation of carcass of lambs WDB

\begin{tabular}{lcccccc}
\hline \multirow{2}{*}{ Variables } & \multicolumn{5}{c}{ Genotypes of sorghum ${ }^{1}$} \\
\cline { 2 - 5 } & BRS 610 & BRS 655 & BRS 800 & BRS 810 & PN \\
\hline Conformation & 2.57 & 2.57 & 2.35 & 2.21 & 2.57 \\
Finishing & 2.50 & 2.35 & 2.57 & 2.64 & 2.57 \\
Marbling & 1.85 & 1.71 & 1.85 & 1.85 & 0.718 \\
Fat thickness (mm) & $1.20 \mathrm{ab}$ & $1.22 \mathrm{ab}$ & $1.15 \mathrm{ab}$ & $0.84 \mathrm{~b}$ & 1.00 \\
Renal-pelvic fat & 2.28 & 1.92 & 2.14 & 2.21 & 0.940 \\
\hline
\end{tabular}

$\mathrm{a}, \mathrm{b}$ in the same row differ by Tukey's test $(\mathrm{P}<0.05)$.

${ }^{1} 610$ - silage of sorghum BRS 610; 655 - silage of sorghum BRS 655; 800 - silage of sorghum BRS 800; 810 - silage of sorghum BRS 810 ; PN - silage of sorghum Ponta Negra. 
an average of 6.79 and 5.64, for the initial and the final $\mathrm{pH}$ (fpH, 24 hours), respectively.

According to Rodrigues et al. (2004), the decrease in $\mathrm{pH}$ and temperature during rigor mortis of the animal carcasses directly influence the quality of the meat, having this decrease controlled mainly by glycogen reserve, $\mathrm{pH}$ and muscle temperature. The values of $\mathrm{fpH}$ found in this study show that there was a good settling of rigor mortis of carcasses during the cooling process, resulting in meat with more desirable sensory properties, ideal for both in natura consumption and for the processing industry.

The silages from different genotypes of sorghum had no effect $(\mathrm{P}>0.05)$ on the degrees of conformation and fattening, RPF, and fat marbling, which averaged 2.37, 2.52, 2.12 and 1.85 , respectively (Table 5). Visual determination of degree of fattening allows for providing carcasses with adequate fat cover for consumers, since, according Osorio and Osorio (2005), the ideal fat cover of the carcasses is defined by the consumer.

Andrade et al. (2009) found degrees of conformation of 3.07, 2.88 and 2.63 for Hampshire Down lambs fed only corn grain silage, $80 \%$ corn grain silage $+20 \%$ sunflower silage or $99 \%$ corn grain $+1 \%$ of urea, respectively. The marbling level of the carcasses was higher than the 1.42, 1.20 and 1.69 reported by Gutiérrez et al. (2005) for Pelibuey, Suffolk $\times$ Pelibuey and Rambouillet $\times$ Pelibuey lambs, respectively. It can be observed that the animals had carcasses with good conformation, indicating a proportional development of distinct anatomical regions comprising the carcass, and an average fattening degree, enough to protect the carcasses from excessive losses during the cooling process and to give the meat a nicer flavor.

The lowest subcutaneous fat thickness was observed in the carcass of the animals fed diet containing sorghum genotype BRS 810, although there was no difference in the composition of the diets or in the weight gain that would justify this purpose. Lombardi et al. (2010), working with lambs that received corn grain silage or corn grain silage with inclusion of sunflower or urea, found values close to those found in this study.

The weights and yields of retail cuts of the carcass were not affected $(\mathrm{P}>0.05)$ by the silage of different genotypes of sorghum (Table 6). The leg was the heaviest cut and, thus, had the highest yield in relation to the left half-carcass, $31.88 \%$, which is because it is a region with greater muscularity and higher yield of the edible part. The average yields of loin and shoulder were of 12.54 and $18.34 \%$, respectively. The leg and the loin are the cuts with the largest commercial value, named prime cuts, in view of their better muscle yield and higher meat tenderness (Cezar and Sousa, 2007).

According to Silva Sobrinho et al. (2005), in meat sheep breeds, the sum of yields of leg, loin and shoulder yield over $60 \%$. In this study, the sum of the yields of these cuts was $62.76 \%$. This value is close to that found by Paim et al. (2013) with crossbred Dorper $\times$ Santa Inês, and higher than that found by Pinto (2009). (59.37\%), in research with Santa Ines lambs, showing that although the lambs have no defined breed, they had yields of prime cuts close to those observed in specialized breeds for meat production. This result highlights the possibility of producing lamb carcasses with high yield even exploiting the genetic resources of that region. For the other cuts, the averages were 7.92 and $29.42 \%$, for the neck and ribs, respectively.

According to the results, it appears that, regardless of the genotype of sorghum used, forage or grain types, the experimental diets showed an excellent composition, meeting the nutritional requirements of the animals, allowing for a good yield of retail cuts.

Table 6 - Weight and yield of retail cuts of lambs WDB fed diets with different genotypes of sorghum

\begin{tabular}{|c|c|c|c|c|c|c|}
\hline \multirow{2}{*}{ Variables } & \multicolumn{5}{|c|}{ Genotypes of sorghum $^{1}$} & \multirow{2}{*}{ P-value } \\
\hline & 610 & 655 & 800 & 810 & $\mathrm{PN}$ & \\
\hline Weight of the cold half-carcass $(\mathrm{kg})$ & 5.48 & 5.65 & 5.59 & 5.73 & 5.60 & 0.972 \\
\hline Neck (kg) & 0.43 & 0.45 & 0.41 & 0.46 & 0.45 & 0.542 \\
\hline Shoulder (kg) & 1.01 & 1.02 & 1.01 & 1.06 & 1.00 & 0.871 \\
\hline Ribs (kg) & 1.62 & 1.66 & 1.69 & 1.68 & 1.61 & 0.969 \\
\hline Loin (kg) & 0.67 & 0.69 & 0.72 & 0.69 & 0.69 & 0.941 \\
\hline Leg $(\mathrm{kg})$ & 1.73 & 1.80 & 1.74 & 1.82 & 1.83 & 0.833 \\
\hline Neck & 8.01 & 7.99 & 7.43 & 8.11 & 8.10 & 0.514 \\
\hline Shoulder & 18.64 & 18.26 & 18.23 & 18.60 & 18.00 & 0.585 \\
\hline Ribs & 29.40 & 29.37 & 30.20 & 29.39 & 28.75 & 0.969 \\
\hline Loin & 12.32 & 12.33 & 12.98 & 12.12 & 12.27 & 0.237 \\
\hline Leg & 31.61 & 32.03 & 31.15 & 31.77 & 32.86 & 0.229 \\
\hline
\end{tabular}




\section{Conclusions}

It is possible to finish sheep without defined breed feeding them diets based on silages of sorghum, regardless of its grain or forage purpose, because they meet the nutritional requirements of the animals, and result in carcasses with high yield and good conformation, likely to meet the market demand for sheep meat.

\section{References}

Alves, E. M.; Pedreira, M. S.; Aguiar, L. V. Coelho, C. P.; Oliveira, C. A. S. and Silva, A. M. P. 2012. Silagem de sorgo com e sem tanino em substituição à silagem de milho na alimentação de ovinos: desempenho e características de carcaça. Ciência Animal Brasileira 13:157-164.

Andrade, M. B.; Macedo, F. A. F.; Jobim, C. C.; Lombardi, L.; Macedo, F. G. and Gasparino, E. 2009. Características da carcaça e da carne de cordeiros terminados com dietas contendo diferentes proporções de silagens de grãos de milho. Acta Scientiarum. Animal Sciences 31:183-189.

Brasil. Ministério da Agricultura Pecuária e Abastecimento. 2007. Regulamento da inspeção industrial e sanitária de produtos de origem animal. Brasília, DF.

Cezar, M. F. 2004. Características da carcaça e adaptabilidade fisiológica de ovinos durante a fase de cria. Tese (D.Sc.). Universidade Federal da Paraíba, Areia.

Cezar, M. F. and Sousa, W. H. 2007. Carcaças ovinas e caprinas obtenção, avaliação e classificação. 1.ed. Editora Agropecuária Tropical, Uberaba.

Colomer-Rocher, F. 1986. Los criterios de calidad de la canal: sus implicaciones biológicas. v.2, 66p. In: Curso Internacional sobre la Producción de Ovino de Carne. Zaragoza, España.

Dantas, A. F.; Pereira Filho, J. M.; Silva, A. M. A.; Santos, E. M.; Sousa, B. B. and Cézar, M. F. 2008. Características da carcaça de ovinos Santa Inês terminados em pastejo e submetidos a diferentes níveis de suplementação. Ciência e Agrotecnologia 32:1280-1286.

Ferreira, D. F. 2008. SISVAR: um programa para análises e ensino de estatística. Revista Symposium 6:36-41.

Garcia, C. A.; Monteiro, A. L. G. and Costa, C. 2003. Medidas objetivas e composição tecidual da carcaça de cordeiros alimentados com diferentes níveis de energia em creep feeding. Revista Brasileira de Zootecnia 32:1380-1390.
Gutiérrez, J.; Rubio, M. S. and Méndez, R. D. 2005. Effects of crossbreeding Mexican Pelibuey sheep with Rambouillet and Suffolk on carcass traits. Meat Science 70:1-5.

Lombardi, L.; Jobim, C. C.; Bumbieris Jr., V. H.; Calixto Jr., M. and Macedo, F. A. F. 2010. Características da carcaça de cordeiros terminados em confinamento recebendo silagem de grãos de milho puro ou com adição de girassol ou uréia. Acta Scientiarum. Animal Sciences 32:263-269.

NRC - National Research Council. 2007. Nutrients requeriments of small ruminants. National Academy Press, Washington, D.C.

Osório, J. C. S. and Osório, M. T. M. 2005. Produção de carne ovina: técnicas de avaliação "in vivo" e na carcaça. UFPEL, Pelotas.

Paim, T. P.; Silva, A. F.; Martins, R. F. S.; Borges, B. O.; Lima, P. M. T.; Cardoso, C. C.; Esteves, G. I. F.; Louvandini, H. and McManus, C. M. 2013. Performance, survivability and carcass traits of crossbred lambs from five paternal breeds with local hair breed Santa Inês ewes. Small Ruminant Research 112:28-34.

Pinto, T. F. 2009. Características da carcaça e qualidade da carne de ovinos Santa Inês alimentados com palma forrageira em substituição ao milho. Dissertação (M.Sc.). Universidade Federal da Paraíba, Areia.

Ribeiro, E. L. A.; Rocha, M. A.; Mizubuti, I. Y. and Silva, L. D. F. 2002. Silagens de girassol (Helianthus annus L.), milho (Zea mays L.) e sorgo (Sorghum bicolor (L.) Moench) para ovelhas em confinamento. Ciência Rural 32:299-302.

Ribeiro, T. M. D.; Costa, C.; Monteiro, A. L. G.; Piazzetta, H. V. L.; Fernandes, M. A. M. and Prado, O. R. 2012. Carcaças e componentes não-carcaça de cordeiros terminados em pasto de azevém recebendo suplementação concentrada. Ciência Rural 42:526-531.

Rodrigues, T. P.; Silva, T. J. P.; Carvalho, E. C. Q.; Freitas, M. Q. and Paulino, F. O. 2004. Caracterização do processo de rigor mortis em músculos de equinos e maciez da carne. Ciência Rural 34:1225-1230.

Sañudo, C. and Sierra, I. 1981. Estudio de la calidad de la canal y de la carne em animales cruzados Romanov por Rasa Aragonesa. 2. Comparación en el tipo comercial ternasco com Rasa en pureza. p.483-489. In: Actas de las 7 Jornadas Científicas de la Sociedad Española de Ovinotecnia. Facultad de Veterinaria, Talavera de la Reina, Espanha.

Silva Sobrinho, A. G.; Silva, A. M. A.; Gonzaga Neto, S.; Zeola, I. M. B. L.; Marques, C. A. T. and Miyagi, E. S. 2005. Sistema de formulação de ração e características in vivo e da carcaça de cordeiros em confinamento. Agropecuária Científica no Semiárido 1:39-45.

Silva, D. J. and Queiroz, A. C. 2002. Análise de alimentos: métodos químicos e biológicos. 3.ed. Universidade Federal de Viçosa, Viçosa, MG, Brasil.

Van Soest, P. J.; Robertson, J. B. and Lewis, B. A. 1991. Symposium: carbohydrate metodology, metabolism, and nutritional implications in dairy cattle. Journal Dairy Science 74:3583-3597. 